\title{
Land Stewardship: Unearthing the Perspectives of Land Managers
}

\author{
Jacqui Dibden, Naomi Mautner and Chris Cocklin*"
}

\begin{abstract}
$\mathrm{A}$ ustralian government and non-government agencies have begun to recognise that the action required to address environmental degradation cannot be considered to be the responsibility of landholders alone, and that some form of encouragement to undertake work in the public interest is required. This article outlines social research, undertaken as part of the Victorian Land Stewardship Project, that explored the key issues that institutional and private land managers regard as influencing resource use decisions by farmers and other landholders, and the types of strategies that may facilitate the adoption of activities which provide ecosystem services. The focus of this article is on the methodological aspects of the social research, notably the combination of landholder participation. sequential small group sessions, and the use of a futures methodology.
\end{abstract}

\section{Introduction}

Environmental conservation and the management of natural resources were once the function of appointed officials in the public sector (Mitchell 1989). More recently, natural resource management has been constructed as a broader project, requiring the direct involvement of rural communities, individual landholders, non-government organisations and even the corporate sector. Partly as a result of the neo-liberal reforms carried out in most western democracies, a tendency has emerged for responsibility for environmental protection and management in support of the public interest to be assigned to private individuals, farmers and other landholders. This has particularly been the case in Australia, Canada and New Zealand, where there has been an emphasis on 'the use of communitybased approaches to address envitonmental issues, through supporting collective action to solve environmental problems. These approaches tend to appeal to farmers' self interest in environmental conservation' (OECD 2003, p. 6).

\footnotetext{
* The authors are with Monash University, Building II, Clayton campas, Wellington Road, Clayton Vic. 3800; Contact athor email:Chris.Cocklin@arts.monash.edu.au.
}

However, the magnitude of the environmental problems afflicting, and created by, agricultural practices in Australia has become increasingly severe and apparent. Australian government and non-government agencies have begun to recognise that the action required to address environmental degradation cannot be considered to be the responsibility of private landholders alone, and that some form of encouragement to undertake work in the public interest is required.

In Victoria, the State Government initiated the Land Stewardship Project to explore the role of private land managers (henceforth referred to as 'landholders') as 'stewards of the land', in recognition of their potential to undertake activities that result in 'public good' ecosystem services, such as maintenance of biodiversity (VCMC/DSE 2003). As part of the Land Stewardship Project, it was recognised that the opinions and needs of landholders are critical determinants of the success of new policy and programs. Landholders make decisions about land management in the context of many complex and competing pressures; a context in which issues as diverse as drought and an aging rural population threaten farm viability and continuity.

This article outlines social research, undertaken as part of the Land Stewardship Project, that explored the key issues that landholders regard as influencing their resource use decisions, and the types of strategies that may facilitate the adoption of activities which provide ecosystem services. The focus is on the methodological aspects of the social research, notably the combination of land manager participation, a short timescale, sequential focus group and workshop sessions, and the use of a futures methodology. The article examines the effectiveness of the methodology as a tool for investigating the attitudes and outlooks of landholders, and for identifying possible future directions and policy preferences. Understanding the strengths and weaknesses of the approach is essential to its effective implementation in support of land stewardship initiatives on a wider basis.

\section{The Land Stewardship Project}

Over the past 15 years, attempts have been made at both Commonwealth and state levels to address environmental 
problems associated with agriculture. Support was provided for landholders and local communities, who were seen as primarily responsible for conservation and remediation of land and water degradation in their local area. This responsibility has often been borne by groups of landholders, acting through voluntary organisations such as Landcare.

However, it has become increasingly apparent that rural people are unable to address major environmental problems adequately, because they are often also struggling to maintain their own economic and social viability - particularly when they derive proportionately little personal benefit from their efforts (VCMC/DSE 2003; Productivity Commission 2004). Moreover, despite the involvement of many landholders in environmental projects, there are indications that they are fighting a losing battle. This has been attributed partly to the inadequacy of the resources committed by governments, or available within local communities, compared to the magnitude of the task (VCMC 2002).

A recognition of the need for new approaches led to the establishment in 2002 of the Land Stewardship Project, a joint initiative of the Victorian Catchment Management Council (VCMC) and the Department of Sustainability and Environment (DSE), with funding from the National Action Plan for Salinity and Water Quality (COA 2005). The aims of this project were to seek new ways to address environmental and socio-economic threats to sustainable resource management in Victoria (VCMC/ DSE 2003). For example, the project investigated policy options, such as the development of new market-based instruments and other forms of payment and investment, to support private landholders undertaking activities considered to be above and beyond their 'duty-of-care' (Young et al. 2003). The project aimed to develop new strategies that would advantage farmers who were providing 'public good' environmental services from the land.

Environmental services or 'ecosystem services' have been defined (VCMC/DSE 2003, p. 1) as:

Those public good services which generally come from natural areas, but which can also result from sustainable management of land and water. Included are the provision of clean air and water, biodiversity services and sequestration of carbon.

The social research component of the Land Stewardship Project was designed as an iterative process, through which landholders' views were incorporated into the identification and evaluation of new approaches. The social research identified the issues confronting landholders, how they responded to these issues, their preferences in terms of policy approaches and tools, and their visions and interpretations of sustainability in the context of land management. The project aimed to provide a context for exchange of aspirations and understandings between institutional stakeholders and landholders, and to identify strategies that could be used by government to facilitate the adoption of sustainable land management practices.

\section{Methodology}

A time period of four months was available for the social research, including research preparation and completion of the final report. This, together with funding constraints and a prescriptive consultancy brief, precluded the use of a mixed methodological approach, including in-depth interviews and a survey, which would have provided additional insights and enabled the results to be generalised (cf., e.g. Kontogianni et al. 2001). The social research for the Land Stewardship Project involved use of focus groups and workshops, supplemented with opportunities for individual expression of views.

Iteration, 'the constant re-evaluation of findings as new data come in' (Taplin et al. 2002, p. 81), was facilitated by a format that consisted of a series of discussions with six groups of participants meeting on three separate occasions over a three month period (July-September 2003). Holding a series of meetings, rather than a one-off consultation, enabled the discussions to move sequentially from consideration of past and present issues to future scenarios and specific policy proposals, and to re-evaluate the findings from each stage in collaboration with participants. Drawing upon the issues and trends identified in the first meeting, four scenarios describing possible 'futures' for agriculture, rural communities and land management were developed by the project team. The scenarios were used in the second round of meetings as the basis for discussion of participants' preferred futures and of strategies and tools to encourage provision of ecosystem services. The third series of meetings was designed to present the project findings to participants and to evaluate the outcomes and methodology. The main discussion points in each of the sessions are summarised in Table 1.

\section{Focus groups and workshops}

Focus groups have been defined as 'a research technique that collects data through group interaction on a topic determined by the researcher' (Morgan 1996, p. 130; see also Krueger 2000). Focus groups have been widely used in market research and more recently in medical research. 
Table 1. The purpose and content of the participant workshops.

\begin{tabular}{|c|c|}
\hline Objectives, issues and questions for discussion & Formats \\
\hline $\begin{array}{l}\text { Session l. } \\
\text { Objectives: } \\
\text { I. elicit views on the issues and concerns of farmers } \\
\text { 2. draw out understandings and interpretations of sustainable land } \\
\text { management. } \\
\text { Discussion questions: } \\
\text { Ilow is furming different now to the past? } \\
\text { What are the main issues today for larmers and rural communities? } \\
\text { In what ways are farmers and rural communitics coping with these issucs? } \\
\text { In light of the strategies farmers are adopting: } \\
\text { - Will some issues go away? } \\
\text { What is sustainable land management? } \\
\text { Is land management going to be more sustainable in the future? In what } \\
\text { ways? } \\
\text { What would help farmers as individuals or families to practice sustainable } \\
\text { land management in the future? }\end{array}$ & Focus groups \\
\hline $\begin{array}{l}\text { Session } 2 \\
\text { Objectives: } \\
\text { I. present and discuss the future scenarios } \\
\text { 2. assess the strengths and weaknesses of policy instruments } \\
\text { 3. review and discuss the concept of payments for ecosystem services. } \\
\text { Discussion qucstions: } \\
\text { 1) Scenarios } \\
\text { - Which scenarios are possible, probable, preferred? } \\
\text { - How should we modify a prelerred seenario to inprove it? } \\
\text { - How environmentally sustainable is the preferred scenario? } \\
\text { 2) Policy instruments } \\
\text { - What would help larmers practice sustainable land management in } \\
\text { the futurc'? } \\
\text { - How do we enlist landholder support to ensure envirnnmental } \\
\text { - Whatainability? } \\
\text { 3) Ecosystem services } \\
\text { - What are the benefits of payments or incentives for the provision of } \\
\text { - What issues would need to be resolved? } \\
\text { - How would payments/incentives tor ecosystem services support } \\
\text { olher elements of the preferred scenario? }\end{array}$ & $\begin{array}{l}\text { Focus groups, } \\
\text { workshops, break-out } \\
\text { groups, group and } \\
\text { individual activities, } \\
\text { presentations }\end{array}$ \\
\hline $\begin{array}{l}\text { Session } 3 \\
\text { Objectives: } \\
\text { 1. review and discuss main outcomes from sessions I \& } 2 \\
\text { 2. conduct a participant evaluation. } \\
\text { Discussion points: } \\
\text { - summary outcomes across the groups in terms of preferred scenarios } \\
\text { - participant preferences lor policy mechanisms and instrutnents } \\
\text { How do we design and implement a sustainable land managenent } \\
\text { future? }\end{array}$ & $\begin{array}{l}\text { Presentations, } \\
\text { roundtable } \\
\text { discussions, } \\
\text { participant evaluation } \\
\text { questionnaire. }\end{array}$ \\
\hline
\end{tabular}

although some researchers have found that difficulties in recruiting focus group members can inflate the time and resources required (Gooch and Jansson 2003, pp. 3-4).

As Macnaghten and Jacobs (1997, p. 11) point out, 'Focus group methodologies do not seek to achieve statistically "representative" samples of "the public". They aim to find participants who are typical (in a sociological sense) of particular groups within society, and then to explore the range of meanings and understandings these participants bring to the subject under discussion.' Where focus groups are used as a means of obtaining public participation in policy development, they are not "conducted with the aim of making wide-ranging generalisations. For the most part, their value lies as much in gathering intelligence relevant to the making of decisions, including outlining ways in which differing positions may be harmonised' (Munton 2003, p. 124).

In the Land Stewardship Project social research, the focus group method (Morgan 1996, 1997) was used for the first meeting with the participants, in which the main topic for discussion was the way in which farming has been evolving (Table 1). For the subsequent two meetings, while group discussions were still a feature, the format was more akin to workshops, involving break-out groups, presentations and activities.

\section{Group composition}

Segmentation is often used in social

They "enable researchers to dig beneath what many see as the "superficial" responses given to questionnaire based surveys' (Macnaghten and Jacobs 1997, p. 11). Kitzinger and Barbour (1999, p. 5) consider that focus groups are particularly suited to the study of attitudes and experiences around specific topics.' They have been seen as having the advantage over other forms of qualitative research of being relatively quick and inexpensive, research, including focus groups and workshops, for two major reasons (Morgan 1996, p. 143):

First. it builds a comparative dimension into the entire research project, including the data analysis. ... Second, segmentation facilitates discussions by making the participants more similar to each other.

In the Land Stewardship Project, the category of 'land manager' was segmented into private landowners and 
'institutional' land managers. The latter included representatives from Catchment Management Authorities (CMAs), government departments, local councils, water authorities and non-government organisations, such as farmer, industry and environmental groups. These categories were further segmented by geographical location. The groups were drawn from two regions of Victoria - North East Victoria and the Wimmera selected because of their CMAs' established interest in land stewardship initiatives.

Three groups were enlisted in each of these CMA regions, one made up of institutional land managers, and two of private landholders. On the advice of the CMAs, two local areas were chosen from which landholders were recruited '. These areas were characterised by a variety of land ownership, farming and landscape types. In particular, within each CMA, one locality was characterised by extensive land subdivision and a greater prevalence of 'post-productivist' land uses (Ilbery and Bowler 1998; Wilson 2001), such as 'lifestyle', production of strawberries, native seeds, goats, horses and deer, agro-forestry, revegetation and tourist accommodation. The contrasting area within each CMA region was dominated to a greater extent by commercial farming operations, such as production of beef, sheep (for meat and wool) and crops. However, while the groups were diverse, they could not be considered representative of the variegated mix of enterprises, social and demographic characteristics, or values, attitudes and behaviours (e.g. Curtis et al. 2003).

A decision was made to maintain separation between the landholders and institutional groups for the first two sessions ${ }^{2}$, both in order to identify differences of perspective and in the belief that landholders would be more constrained in expressing their views in the presence of representatives of government agencies. The validity of this latter view was reinforced by several landholders, who remarked favourably on the fact that their groups were made up entirely of landholders. The landholder groups were differentiated in terms of individual farming (or non-farming) activities and by the types of landholding and land-use prevalent in their local areas.

However, the 'institutional' and landholder groups were not mutually exclusive, as several 'institutional' participants reported that they were not only professionally employed in resource management but were also private landowners. In addition, several landholders had a good deal of experience with the institutional aspects of natural resource management and decision-making through extensive involvement on committees of CMAs, Landcare groups, Victorian Farmers Federation and other organisations.

Although it had been anticipated that different perspectives would emerge from the different land manager groups, in practice the views expressed by both groups proved to be quite closely aligned; the major difference was that institutional land managers displayed a greater familiarity with government policies and programs. Indeed, there was as much diversity of opinion within some groups as between different types of group. As Gooch and Jansson (2003, p. 5) point out, 'while a group may be homogeneous in terms of background, [it] is not self-evident that participants within the same group hold common opinions.'

\section{Recruitment}

The composition of groups is shaped not only by the choices of the researchers but also by the willingness of individuals to participate. This has been regarded as introducing potential bias to groups, particularly if the aim of the research is to explore the views of participants representing a range of views and experiences. As Gibson et al. (1999) argue, people prepared to spend the time are generally those with a stronger interest in the issues being discussed.

In an attempt to achieve a wide mix of participants, a strategy was proposed using multiple 'starting points' for the snowball recruitment process. However, the recruitment process was constrained by a short timeframe, and further confounded by privacy legislation that prohibits agencies from providing the contact details of private individuals. Reflecting the particularly strong commitment of the two CMAs to the project, the majority of the participants were contacted with the assistance of the CMAs. The recruitment of the participants was also assisted by recommendations from the Victorian Farmers Federation, Landcare groups and local offices of the Departments of Sustainability and Environment (DSE) and Primary Industries (DPI).

\footnotetext{
1. Within the Wimmera CMA. these areas were the South-west Wimmera (around Edenhope) and the Upper Wimmera (centred on Ararat). In the North East, the areils chosen were around Wooragee and Rutherglen (in the vicinity of the regional city of Albury-Wodongia) and the Upper Murray (around Corryong, in the foothills of the Suowy Mountains).

2. For the third session, the groups were combined to allow for the constructive sharing of views in rebation to the summary of research findings. However, no institutional representative attended the third session in Corryong. although it wats attended by a representative of the project steering connmittee.
} 
A consequence of the increasingly necessary 'dependency on gatekeepers' for recruitment is that 'the gatekeeper may screen potential participants' (Kitzinger and Barbour 1999, p. 10). In recruiting private landholders through these organisations, it was emphasised that a diversity of landholders was preferred. A mix of ages, farm types and gender representation was in fact achieved. The landholders included both commercial farmers and 'hobby' or 'lifestyle' landholders, whose holdings are used for small-scale production or non-commercial proposes. Most landholders were older than 40 (with 59 per cent older than 50) and 32 per cent were female.

Recruiting and maintaining groups of a workable size (set at 10-12 participants) was achieved by contacting each participant by telephone and in writing before the first meeting, and in writing before each of the subsequent two workshops. Meeting dates and times were arranged in consultation with the groups, though inevitably it was impossible to identify a time suitable for all. Participants were paid a token amount of $\$ 50$ for expenses for each session they attended. A total of 56 landholders and 18 institutional land managers participated, although some were unable to attend all three sessions. However, retention rates over the series of meetings were generally good $^{3}$.

Despite the efforts to counter it, participation was almost certainly 'biased' in the same way that Gibson et al. (1999) found, in that there was a tilt towards those interested in issues of sustainable land management. This has important implications for the use of the social research in policy and strategy development. The participants cannot be assumed to be representative of the entire range of landholders or institutional land managers. While these concerns apply particularly to qualitative research methods, even in the case of a random sample survey in New Zealand, Rhodes et al. (2002, p. 673) acknowledged that 'it remains possible that the sample was biased towards those who are more interested in the topic ... and application of the conclusions made from this study to a wider group of farmers should therefore be catried out with caution.'

However, it could be argued that this potential bias need not be a matter of concern in a research project focusing on the probability of particular interventions being adopted, and on the measures required to ensure their success. This is because there is a high likelihood that those landholders first adopting a new initiative will be precisely those most interested in finding out more about such a possibility through participation in a research project. Of course, the probability of wider uptake of improved land management strategies. would, in turn, need to be assessed more explicitly.

\section{Mixed methods}

Eliciting relevant information of a sensitive or confidential nature (e.g. the effect of high debt levels on participants' receptiveness to conservation) may be inhibited in group processes (Maybery et al. 2005; Seal et al. 1998). Group meetings are therefore sometimes supplemented with quantitative techniques (e.g. a survey) or with further qualitative work (e.g. one-on-one interviews; Krueger 2000; Morgan 1996, 1997). For example, a combination of focus groups and questionnaires was used by Kontagianni et al. (2001) and focus groups with interviews by Taplin et al. (2002). Maybery et al. (2005), in a study of farming values, used interviews and a questionnaire in conjunction with focus groups.

Because of the limitations in time and resources in this project, more modest means were devised to gather supplementary information and feedback. For example, participants were provided with forms during each meeting to record their individual views on some issues. These forms proved to be an especially valuable record of information for the project team. To provide an opportunity to communicate confidential information or further observations, individual questionnaires incorporating the main points of discussion were handed out to each participant with a reply-paid envelope. Approximately one-third of these were returned following the first focus group meeting, but only four questionnaires were received after the subsequent workshop, possibly because the discussion was centred less on issues of a personal nature. The invitation to discuss issues further by telephone was also taken up by several of the participants.

\section{Futures Approach}

A 'futures' research approach was implemented through the development and discussion of scenarios. This approach has not been widely used by natural resource management organisations (McDine 200I) despite being employed extensively in both private and public sector planning. According to Dunlop (2001, p. 4), 'the discipline of scenario planning has evolved to help planners and policy makers cope with uncertainty in the

3. For example, the Corryong group recorded 64 per cent of participants attending all three sessions. 
future and our natural tendency to ignore it.' Scenarios have been seen as promoting new ways of looking at problems (Glassheim et al. 2004, p. 45):

Future scenarios offer an opportunity to let go of the present and take a freer look at the future. They allow participants to understand the structural nature of changes and hence to go beyond tunnel vision. Scenarios are also a learning tool, encouraging different approaches to looking at reality in alternative ways, as well as a risk assessment tool for identifying basic uncertainties in the overall setting.

Parminter et al. (2003, p. 3) note that scenarios generate a 'deeper understanding' of complex issues, and 'can describe a chain or sequence of events... or the depiction of a situation at a specific time period'. There are several criteria that establish a good scenario, it should be: plausible, internally consistent, relevant, recognisable in terms of current conditions, challenging, and contain 'elements of surprise' (ASTEC 1996).

In the first meeting, participants discussed farming in the past, the issues affecting them now, and the issues that they thought would be important in 2020. Many landholders saw the past as a time when it was possible to make a living from a farm that was small by today's standards, and when rural employment was more readily available. By contrast, farms in recent decades have needed to grow in size, with 'larger areas managed by fewer people' (landholder participant, July 2003) ${ }^{4}$. Several factors were seen as underlying this shift:

... tighter margins, higher expectations, need for higher education, taxes (direct and indirect) and the cost of complying, drought, interest rates, bad luck, bad management would be just some reasons for the demise of the smaller farm (landholder participant, July 2003).

Table 2. Current concerns of landholders.

\begin{tabular}{|c|c|c|}
\hline Issue & $\begin{array}{l}\text { Percent } \\
\text { reporting }\end{array}$ & Commentury \\
\hline $\begin{array}{l}\text { Farm business/ } \\
\text { economic issues }\end{array}$ & $76 \%$ & $\begin{array}{l}\text { Commodity prices, particularly low prices relative to costs (the } \\
\text { cost-price squeeze) and the volatility of prices on the world } \\
\text { market. Low prolitability impacting adversely on the ability to } \\
\text { farm sustainably }\end{array}$ \\
\hline $\begin{array}{l}\text { Government } \\
\text { policy/ } \\
\text { regulittion }\end{array}$ & $54 \%$ & $\begin{array}{l}\text { "Over-regulation' by government and the cost of compliance - } \\
\text { both lintancial and in lerms of time spent un patperwork, } \\
\text { including industry and legal obligations such as Occupational } \\
\text { Health and Safety and quality assurance mcisures }\end{array}$ \\
\hline $\begin{array}{l}\text { Environunciltal/ } \\
\text { NRM issucs }\end{array}$ & $54 \%$ & Water availability and quality, pests, salinity and erosion \\
\hline $\begin{array}{l}\text { Social/ } \\
\text { comunumily } \\
\text { isstues }\end{array}$ & $48 \%$ & $\begin{array}{l}\text { Population decline, associated with a rediction in services } \\
\text { and infrastructure. A lack of employment opportunities for } \\
\text { youth, and limited intergenerational trinsfer of firms, halve } \\
\text { resulked in an agcing farm and rural town population. } \\
\text { Volunteer burnout is common, jeopardising the future of } \\
\text { community activities, including Landcare }\end{array}$ \\
\hline
\end{tabular}

Although farms have become 'bigger to be viable', viability also requires manaing with a smaller workforce. Because of financial pressures, related to 'markets that are boom/bust and unreliable',

... farming has gone onto a business footing, similar to a factory or the corner store. There is a stronger emphasis on return on capital (landholder participant, July 2003).

Overhead costs have increased, with a greater dependence on chemical inputs and use of modern machinery that is more expensive and requires specific skills to operate. Farms have had to become more efficient and productive, which some saw as carrying increasing burdens, particularly in conjunction with an increase in regulation and paperwork.

Others saw advantages in the increasing technical sophistication of farming and the extension of its knowledge base:

The expectations of modern life place upon us pressure to take up scientific and production advancements available to use to achieve production and financial goals we set for ourselves ... Perhaps nostalgic reflections of the past do not really reflect the realities of those times. We may well be better off these days as our options in life are certainly broader - we at least have the means to change direction and try something else if we wish to (landholder participant, July 2003).

Some saw increased knowledge as including greater understanding of environmental impacts:

We probably have more awareness of the effects our enterprises are having on the natural environment. Some things we can therefore do differently, such as fence streams and native vegetation to control grazing pressure (landholder participant, July 2003).

One aspect of farming which had not changed was its dependence on the vagaries of nature. As one landholder (July 2003) commented, 'farming is, and always has been, a job not for the nervous!'

Other issues preoccupying the landholders were economic issues, environmental concerns, the role of government and social issues (Table 2).

In many respects, the participants envisaged the year 2020 as an extrapolation of current trends. The research team synthesised these 'visions' to develop four scenarios spanning a time period from the

4. Quotations are not attributed to specific workshop participants to maintuin contidentiality. 
present to the year 2020. The scenarios described a set of hypothetical futures for agriculture, rural communities and land management.

Each scenario was given an 'evocative name' designed to 'capture the essence of the scenario and easily allow differences between the scenarios to be recalled' (ASTEC 1996). These hypothetical futures ranged from environmentally destructive to comparatively sustainable.

- At one extreme was a bleak prospect (entitled 'It's hard to be green when you're in the red'), featuring diminishing returns to farming, the increasing subsumption of the family farm, declining rural populations, and increased degradation of the natural environment. Under these conditions, it was projected that farmers would be risk averse, tied to their suppliers and purchasers, and focused on making ends meet financially.

- A second scenario - titled 'Plodding on' - described a future in which both public and political interest in the environment wanes, productivist agriculture becomes even more entrenched, and farm numbers continue to decline.

- A more optimistic scenario ('Farming smarter') described rural futures featuring improved farming conditions based on new technologies and management systems, increased spending by governments on research and development, a focus on long-term productivity, revitalisation of rural communities, and improved environmental outcomes. With better economic returns, farmers might be more inclined to pursue higher-risk strategies (e.g. new niche products) and they might also be in a better position to retire marginal land from production.

- Another optimistic scenario ('The grass is greener') envisaged 'an upsurge in interest in environmental issues and the health and safety aspects of food production', accompanied by an increased willingness of consumers to 'pay extra for products with good health and environmental credentials' (Cocklin et al. 2003, pp. 18-23).

The scenarios were mailed to participants approximately 10 days prior to the second meeting. At these workshops, discussion focused on participants' assessment both of the detail in each scenario and the hypothetical future represented by the scenario as a whole. The participants also 'voted' for their preferred scenario, and were then asked to indicate how it might be improved.

All four scenarios were assessed as 'possible'. Many participants commented that elements of each scenario could happen, and indeed many are happening, in different regions of Victoria. The first scenario ('It's hard to be green when you're in the red') is, from most perspectives, the most pessimistic of the four. This future was seen as the least probable and was not selected as the preferred scenario by any of the participants. Workshop participants commented that it was a picture of what they had experienced in the past - like 'looking back 5-10 years' - rather than depicting the present situation or what was likely, or desirable, for the future. Participants did not regard the second scenario ('Plodding on') as probable either, and no-one preferred it in its entirety, although some participants identified desirable elements notably, suggestions of increased cooperation among landholders and less government regulation.

In terms of a preferred future, all participants 'voted' for either the third ('Farming smarter') or fourth ('The grass is greener') scenario. 'Farming smarter' was the future favoured by the largest number of workshop participants, with 60 per cent identifying it as their preferred scenario. Many participants were keen to see improved economic conditions linked to an increased likelihood of young people returning to rural areas, and stabilising rural populations. This was also seen as the most probable scenario - a vision of a 'self-reinforcing system, driven by new technology and better business operations, creating improved returns that are reinvested in the system'; this future would also be marked by a 'cultural shift towards recognition of the mutual benefits of making a profit and looking after the environment' (Cocklin et al. 2003, p. 20).

Overall, 'The grass is greener' scenario was voted second in terms of being both 'probable' and 'preferred' (by 40 per cent of participants). Those who favoured this scenario liked the suggested upsurge in consumer interest in the environment accompanied by a willingness to pay for better environmental performance. Whereas the 'Farming smarter' scenario emphasises a more skilled and educated producer community, 'The grass is greener' scenario was characterised by a more aware consumer society, informed about production practices and prepared to pay for higher standards.

The preferred scenario emerging from the workshops was a combination of the latter two - a future that is both 'smart and environmentally sustainable' (Cocklin et al. 2003 , p. 24). The participants' support for this future was founded partly on the prospect of improved economic returns to farming, but there was a great deal more to it than that. Investments in new technologies and farming methods, a wider public acknowledgment of the need for 


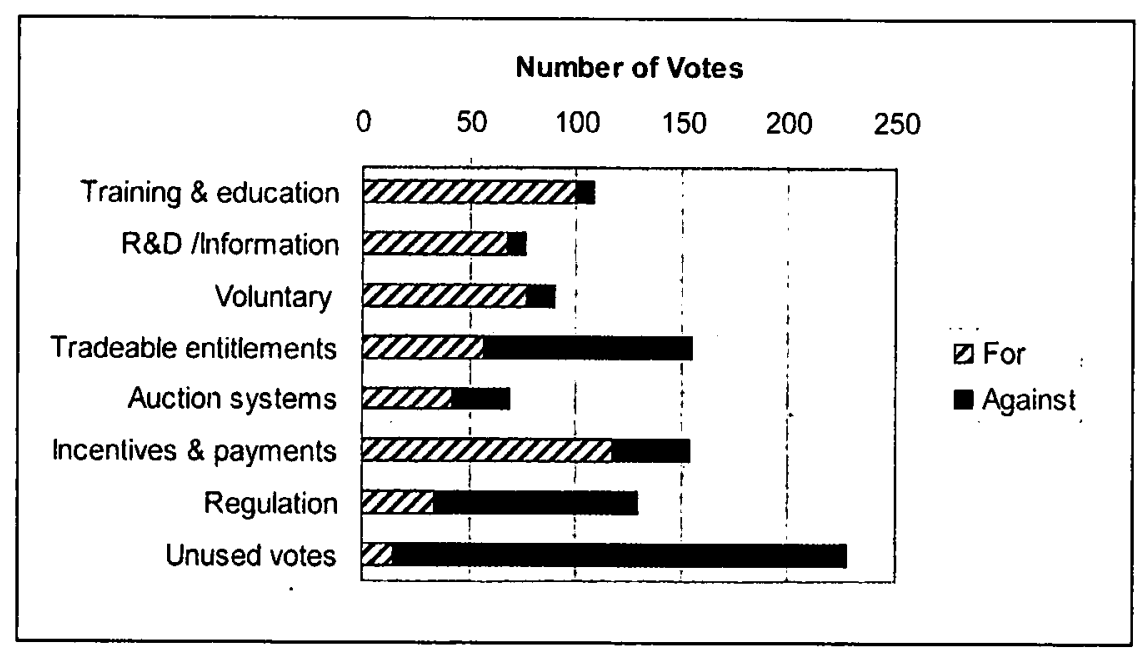

Figure 1. Preferences for policy mechanisms.

improved environmental performance (and a willingness amongst the public to pay for it), and the suggestions of more vibrant and viable rural communities were widely pointed to as features of their preferred futures. An interesting aspect of these conversations was the fact that landholders not only preferred the more optimistic futures, but they also considered them to be more likely.

The purpose of the scenarios was to help participants explore the ways in which agriculture, rural communities and land management might develop to the year 2020 as a background to the choices they (as individuals and as members of groups and communities) might make. Drawing on the probable and preferred futures described, participants moved on to discuss strategies and tools that might be used by government to encourage sustainable land management and provision of ecosystem services. They debated the use of a range of policy tools or instruments - voluntary, market-or price-based, and regulatory.

Unsurprisingly, these discussions revealed an antipathy towards regulatory approaches, and an enthusiasm for voluntary and education-based strategies. Participants were asked to record their preferences for these policy instruments via a 'voting' process. Each participant was given 20 coloured stickers to use as 'votes' - 10 green for positive votes and 10 red as negative votes. Participants could spread their votes as they liked - for example, if they strongly preferred tradeable resource entitlements, they could use all of their green stickers to 'vote' for that mechanism. Interestingly, many participants showed a preference for an affirmative approach and chose not to allocate all of their negative votes. The exercise yielded a useful visual tool (Figure 1), representing the collective preferences of participants for environmental policy mechanisms.

In Victoria, most of these policy mechanisms are already in use; in general, the participants in this research supported their continued use as part of an integrated strategy for promoting sustainable practices within the rural landscape. Our dialogue with participants suggests, however, that from a landholder perspective, the strategy should consist of a hierarchical mix of policy instruments:

- R\&D, training and education, and voluntary programs, the mechanisms most favoured by landholders

- market-like mechanisms, which received 'in principle' support from participants, moderated by concerns for their operational aspects

- regulation, viewed by landholders as a measure of last resort, ensuring minimum standards are maintained.

Several themes emerged from the workshops that represent 'key criteria for successful programs' from the viewpoint of both landholders and institutional land managers. A framework for sustainable land management and the wider provision of ecosystem services was proposed that recognises and supports the role and rights of landholders as stewards of the land; is fair and equitable; is not administratively onerous to access or implement; is adapted to local conditions; and is based on a long-term, coordinated commitment by government. An expressed preference for flexibility, regional or local variation, and an outcomes-based rather than prescriptive approach suggests the appropriateness of a regionally defined 'duty of care' as an essential concept for achieving environmental benefits (Young et al. 2003).

A perception of negative public attitudes towards farming practices and the desire for positive recognition were strong and recurrent themes throughout the discussions. The idea of some form of support and assistance provided by the whole community in acknowledgement of the stewardship role of farmers was strongly supported by many participants. For example,

... acknowledge that I. the farmer, receive NO benefit for many works carried out on my property for the reputed benefit of the whole community. Acknowledge the true total cost to me of environmental actions of no benefit to me but carried out [ass] a good steward of land temporarily under my carre ...(landholder participant. August 2003). 
Generally, participants supported the idea of some kind of reward for the provision of ecosystem services. However, many were sceptical that there would be adequate remuneration to compensate for the costs in time, labour, resources and income foregone, or to improve farm viability.

Criteria for successful policy, from the perspectives of the Land Stewardship Project participants, can be summarised into four themes:

(1) implementation requirements, which include recognition and rewards for early adopters, straightforward rules and guidelines, and access by all landholders to programs and incentives on a nondiscriminatory basis

(2) integration of policy mechanisms. New strategies are more likely to be accepted by landholders if they include education, training and information provision. Information must be communicated in a way that is practical for landholders to apply. Education should be combined with 'advice and incentives - [we] must balance profitability with protecting environment' (landholder participant, July 2003).

(3) the role of government. Landholders need to feel confident that programs and strategies will be ongoing, and that government has a genuine, long-term commitment to them. Some landholders observed that agencies are continually changing their approach without appreciating the implications for landholders, and that overlapping programs and responsibilities result in confusion and wasted time. Also, there is apprehension about loss of control of land

(4) incentives for landholder participation. Landholders expressed the desire to understand how their activities fit with wider (e.g. catchment scale) objectives and to be better informed about what the 'big picture' is. A common theme throughout the discussions was anxiety about public attitudes towards farming practices and a desire for landholders to be recognised for the environmental work they are already undertaking. Public recognition and promotion of the role of farmers and other landholders would constitute a significant motivational incentive for improved land management. Financial incentives need to be realistic, compensating for lost productivity or income foregone, and/or covering the actual cost of both labour and materials required for on-ground work.

\section{Participant evaluation}

Participant evaluation of the consultation process was conducted toward the end of the third workshop, with two-thirds of landholders and almost half of institutional land managers completing evaluation forms ${ }^{5}$. The evaluation canvassed participants' views on holding a series of meetings, the use of scenarios, and their perceptions of involvement in the policy process. A close review of the responses revealed no systematic differences between the responses of the institutional representatives and the landholders.

Scenarios have been seen as a way 'to challenge preconceptions and stimulate discussion about what the future could be like' (Dunlop 2003, p. 1). A small number of participants expressed the view that the scenarios constrained the discussion, but the more common view was that the scenarios provided a good basis for discussion and promoted thinking about the longer term. As one farmer (September 2005) offered,

So often we concentrate on day to day short-term goals, therefore the scenarios promoted thought about mediumterm goals.

All participants responded that it was worthwhile for them to have participated in the discussions; most commonly citing the opportunity to learn about issues, interact with others and share views. Responses to having a series of meetings (rather than just one) were generally favourable.

The workshops challenged us as farmers to look at our farming practices, to stop and think how we were working with the environment, and to speak up about what we needed to improve our current practices. It challenged the group to envisage their farming future, how they envisaged community involvement and commitment, and future protection of the environment, alongside good and profitable farming (landholder participant, September 2005).

The most commonly reported, positive outcome was the opportunity to think issues through and to learn more about other peoples' views.

Sometimes you don't think about things unless someone shines a torch upon them, farmers can work a little close to the coalface and not consider the bigger picture. Workshops such as this help widen the perspective (landholder participant, September 2005).

There was also a sense of hope expressed by several participants that they had contributed to the shaping of policy and strategy in terms of sustainable land

5. A total of 39 evaluation forms were completed, seven by institutional' land manigers and the rembining 32 by private landlisklers. Four people who could not attend the third session submitted evaluations by post. Three respondents had participated in mly one of the three rounds of meetings. ten had participated in two rounds, and the temaining 26 hat patticipated in all three rounds. 
management, and that landholders might be involved in policy and planning. Others referred to the need for the information arising from the project to be published and circulated widely. There were also expressions of hope that there might be an improved understanding of the circumstances of landholders amongst the broader community.

The participants' evaluation of both the process and the outcomes was clearly positive. However, because participation was voluntary, and the formal evaluation process was conducted at the last series of meetings, it is necessary to consider the question of 'survivor bias' in the evaluation. The project time schedule did not permit the team to determine whether people stopped attending because of dissatisfaction with the project or for other reasons. One participant revealed in an informal discussion that he did not attend the third meeting due to frustration with the views expressed by other group members. Other landholders expressed disappointment that they had been unable to attend all meetings because of farm and family commitments; several sent another family member in their place. Ideally, the consultation process would have allowed more time and resources to conduct a robust analysis towards the end of the project, including one-on-one interviews with participants.

\section{Improving the Method}

A feature of qualitative research is that the results cannot be extrapolated and generalised. They provide a 'snapshot' of landholder perceptions at a particular time and in particular areas. Although we have suggested that those landholders who participated were in many cases those most interested in contemplating new directions, the groups cannot be considered to be representative even of this subset of the farming and landowning population. At the time of the project, some landholders were facing substantial hardship due to the drought, and many farmers who might otherwise have participated could not afford the time away from dealing with critical farm needs, particularly feeding stock that were at risk.

In light of these circumstances, it is important to view this work as 'social research' and not as a public consultation process; broad-based public input was not the objective. However, it would have enhanced the research if additional time and resources had been allowed for adequate, location-specific, preparatory research and interviews with key informants before and after the meetings to identify important areas for discussion and analysis.
A weakness was the lack of clarity amongst the institutions involved in the Land Stewardship Project about the future direction and probable outcomes of the project, or the likelihood that government agencies would take the recommendations of the project on board. This made it difficult to provide assurances to participants that they were not wasting their time and that their views would be fully considered. It was also not possible to promise participants that they would have the opportunity to participate in further development of proposals generated or canvassed during the group discussions. This kind of flawed process has also been noted by Munton (2003, pp. 109, 113), who comments that:

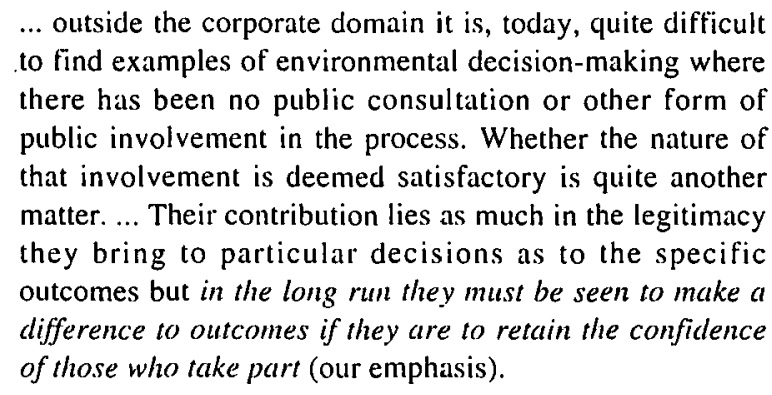

Although the project allowed for a two-way flow of communication between government and landholders, the dominant direction of flow was 'information in', that is, from the landholders to government. While this has its limitations, many participants commented in the evaluation that they appreciated the opportunity to hear the views of other landholders and had personally gained from the experience. Three suggestions offered by the participants in terms of the process warrant particular consideration:

(1) Processes such as the one used in this project would benefit from the presentation of more information on the policy context at the beginning.

(2) There needs to be a 'feedback loop' that ensures the effective carriage of the information from a project such as this into policy recommendations.

(3) A mechanism should be established to ensure the participants are kept informed, directly, about the outcomes.

Group discussions of this kind have the potential to both promote social learning and act as sounding boards for new policies and programs (cf. Bills and Gross 2005; Davies 1999; Walker 2004). They have been used in Europe within the agri-lood sector 'as a means to animate inter-professional debate or discussion in which highly competitive actors find themselves obliged to consider one another's opinions' (Latourcade and Chapuy 2000, p. 
77). In Belgium, the 'scenario method' has been used as a 'powerful tool' for resolving conflicts, for example between producers and conservationists, by bringing together all stakeholders 'in a structured setting ... to listen to the concerns of the other' (Glassheim et al. 2004, p. 46):

... by focusing on big picture trends impacting the industry, the scenario process created space for producers to see what they have in common with other sectors of the food industry which will also be impacted by the anticipated changes. The scenario development process also created opportunities for sectors to co-operate in generating win-win responses to common problems.

The use of scenario planning has the potential to encourage new ideas not only in landholders but in those who make decisions affecting their futures. Ideally, policy-makers would participate in, or closely observe, group discussions to break down the present barriers of misunderstanding and hostility expressed towards remote decision-makers in the 'city'. To ensure effective contributions to policy development, the participation and commitment of policy-makers is essential but has proved difficult to achieve.

\section{Acknowledgments}

This article is based on work carried out under contract to the Department of Sustainability and Environment (DSE), State Government of Victoria. The Land Stewardship Project, of which this work was a part, is a collaborative initiative involving the Victorian Catchment Management Council (VCMC) and DSE. The views expressed are not necessarily those of the DSE or the VCMC.

\section{References}

Australian Science and Technology Council (ASTEC). 1996. Developing Long-term Strategies for Science and Technology in Australia. Appendix 1. More About Foresight. ASTEC, Department of Education, Science and Training, Canberra. Online at http://www.dest.gov.au/archive/Science/astec/ future/findings/appl.html (accessed 25 July 2003).

Bills, N. and Gross, D. 2005. Sustaining multifunctional agricultural landscapes: Comparing stakeholder perspectives in New York (US) and England (UK). Land Use Policy, 22: 313 321.

Cocklin, C., Dibden, J. and Mautner, N. 2003. Stewards of the Land: Landholder Perspectives on Sustainable Land Management. Report prepared for the Victorian Catchment Management Council and Department of Sustainability and Environment. Department of Sustainability and Environment, Government of Victoria, Melbourne.
Commonwealth of Australia (COA). 2005. National Action Plan for Salinity and Water Quality. COA, Canberra. Online at http://www.napswq.gov.au/ (accessed 14 November 2005).

Curtis, A., Byron, I. and McDonald, S. 2003. Integrating spatially referenced social and biophysical data to explore landholder responses to dryland salinity in Australia. Journal of Environmental Management, 68(4): 397-407.

Davies, A. 1999. Where do we go from here? Environmental focus groups and planning policy formation. Local Environment, 4: 295-316.

Dunlop, M. 2001. A Scenario Planning Framework for Australian Landscapes. Resource Futures Program Draft Working Paper 2001/11. CSIRO Sustainable Ecosystems, Canberra.

Dunlop, M. 2003. Taking a long view of land use in Australia. In Proceedings of the In Search of Sustainability Face to Face conference, Canberra, Friday 14th November 2003. Australia 21 Ltd, Nature and Society Forum Inc, Sustainable Population Australia Inc, Canberra, and The Australian Collaboration, Albert Park, Victoria. Online at: www.isosconference.org.au/ entry.html (accessed 18 July 2003).

Gibson, K., Cameron, J. and Veno, A. 1999. Negotiating Restructuring: A Study of Regional Communities Experiencing Rapid Social and Economic Change. AHURI Working Paper No. 11. Australian Housing and Urban Research Institute, Melbourne.

Glassheim, E., Nagel, J. and Roele, C. 2004. The New Marketplace in European Agriculture: Environmental and Social Values within the Food Chain. Northern Great Plains Inc., University of Minnesota, Crookston, Minnesota.

Gooch, G.D. and Jansson, G. 2003. River Dialogue - A Story of Information Communication and Public Participation in Estonia. The Netherlands and Sweden. Focus group methodology in water basin management. Paper presented at the: Monitoring Tailor-Made IV Conference, Information to Support Sustainable Water Management: From Local to Global Levels, 15-18 September 2003, St. Michielsgestel, Netherlands. Conference Secretariat Monitoring Tailor-Made IV, Lelystad, The Netherlands. Online at http://www.mtm-conference.nl/ (accessed 7 November 2005).

llbery, B.W. and Bowler, I. 1998. From agricultural productivism to post-productivism. In: Ilbery, B. (ed.) The Geography of Rural Change. pp. 57-84. Longman, London.

Kitzinger, J. and Barbour, R. 1999. Introduction. In: Barbour, R. and Kitzinger, J. (eds), Developing Focus Group Research: Politics, Theory and Practice, pp. 1-20. Sage, London.

Kontogianni, A., Skourtis, M.S., Langford, I.H., Batteman, I.J. and Georgiou, S. 2001. Integrating stakeholder analysis in nonmarket valuation of environmental assets. Ecological Economics, 37: 123-138.

Krueger. R. 2000. Focus Groups: A Practical Guide for Applied Research. Sage, London.

Lafourcade, B. and Chapuy, P. 2000. Scenarios and actors' strategies: The case of the agri-food sector. Technological Forecasting and Social Change. 65: 67-80. 
Macnaghten, P. and Jacobs, M. 1997. Public identification with sustainable development: Investigating cultural barriers to participation. Global Environmental Change Part A, 7(1): 5-24.

Maybery, D., Crase, L. and Gullifer, C. 2005. Categorising farming values as economic, conservation and lifestyle. Journal of Economic Psychology, 26: 59-72.

McDine, C. 2001. Analysis of methods of futures analysis and scenario testing for Victoria landscapes. Centre for Land Protection and Research, Technical Report No.75. Victorian Department of Natural Resources and Environment, Bendigo.

Mitchell, B. 1989. Geography and Resource Analysis. Second Edition. Longman, Harlow, Essex.

Morgan, D.L. 1996. Focus groups. Annual Review of Sociology, 22: 129-152.

Morgan, D.L. 1997. Focus Groups as Qualitative Research. Second Edition. Sage Publications, Thousand Oaks, California.

Munton, R. 2003. Deliberative democracy and environmental decision-making. In: Berkhout, F., Leach, M. and Scoones, I. (eds), Negotiating Environmental Change: New Perspectives from Social Science, pp. 109-136. Edward Elgar, Cheltenham.

Organisation for Economic Co-operation and Development (OECD). 2003. Agri-environmental Policy Measures: Overview of Developments. Prepared by the Joint Working Party on Agriculture and the Environment, Directorate for Food, Agriculture and Fisheries. Online at www.oecd.org/dataoecd/25/46/18987100.pdf (accessed 19 December 2003).

Parminter, T., Nolan, I. and Bodeker, P. 2003. Use of Scenarios in Industry Consultation: Dairy Insight's Future Focus Project. Paper presented at the NZ Agricultural and Resource Economics Conference 2003, July 4-5 2003, Blenheim, New Zealand. New Zealand Agricultural and Resource Economics Society, Christchurch, New Zealand.

Productivity Commission (PC). 2004. Impacts of Native Vegetation and Biodiversity Regulations: Productivity Commission. PC, Canberra. Online at: http://www.pc.gov.au/inquiry/nativevegetation/finalreport/nativ evegetation.pdf (accessed 14 November 2005).

Rhodes, H., Leland, L. and Niven, B. 2002. Farmers, streams, information, and money: Does informing farmers about riparian management have any effect? Environmental Management, 30(5): 665-677.

Seal, D.W., Bogart, L.M. \& Ehrhardt, A.A. 1998. Small group dynamics: The utility of focus group discussions as a research method. Group Dynamics, 2(4): 253-266.

Taplin, D., Scheld, S. and Low, S.M. 2002. Rapid ethnographic assessment in urban parks: A case study of Independence National Historical Park. Human Organization, 61(1): 80-93.

Victorian Catchment Management Council (VCMC). 2002. The Health of Our Catchments: A Victorian Report Card 2002. The Victorian Catchment Management Council 5 Year Report. VCMC, Melbourne.

Victorian Catchment Management Council/Department of Sustainability and Environment (VCMC/DSE). 2003.
Ecosystem Services through Land Stewardship Practices: Issues and Options. Department of Sustainability and Environment, Melbourne.

Walker, G.B. 2004. The Roadless Areas Initiative as national policy: Is public participation and oxymoron? In: Depoe, S.P., Delicath, J.W. and Elsenbeer, M.A. (eds), Communication and Public Participation in Environmental Decision Making. pp. 113-135. State University of New York Press, Albany, New York.

Wilson, G.A. 2001. From productivism to post-productivism ... and back again? Exploring the (un)changed natural and mental landscapes of European agriculture. Transactions of the Institute of British Geographers, 26(1): 77-102.

Young, M., Shi, T. and Crosthwaite, J. 2003. Duty of Care: An Instrument for Increasing the Effectiveness of Catchment Management. Department of Sustainability and Environment, Melbourne. 